Article

\title{
Biostimulation of Maize (Zea mays) and Irrigation Management Improved Crop Growth and Water Use under Controlled Environment
}

\author{
Kuan-Hung Lin ${ }^{1,+}$, Furn-Wei Lin ${ }^{2,+}$, Chun-Wei Wu ${ }^{3, *}$ and Yu-Sen Chang ${ }^{2, *}$ \\ 1 Department of Horticulture and Biotechnology, Chinese Culture University, Taipei 111, Taiwan; \\ rlin@faculty.pccu.edu.tw \\ 2 Department of Horticulture and Landscape Architecture, National Taiwan University, Taipei 106, Taiwan; \\ r03628135@ntu.edu.tw \\ 3 Department of Horticulture, National Ilan University, Yilan 260, Taiwan \\ * Correspondence: r88628115@gmail.com (C.-W.W.); yschang@ntu.edu.tw (Y.-S.C.); \\ Tel.: +88-623-366-4856 (Y.-S.C.) \\ + These authors contributed equally to this work.
}

Received: 15 August 2019; Accepted: 14 September 2019; Published: 17 September 2019

check for updates

\begin{abstract}
Water deficits during the growing season are a major factor limiting crop production. Therefore, reducing water use during crop production by the application of regulated deficit irrigation (RDI) is crucially important in water resources. There are few reports on the biostimulants used for growth and water use efficiency (WUE) in maize (Zea mays Linn.) under RDI. Therefore, the influence of betaine and chitin treatments, alone and in combination, on maize cultivar 'White Pearl' was assessed by observing changes in the physiology and morphology of plants exposed to RDI. Plants were grown in plastic pots in greenhouses and maintained under full irrigation (FI) for 1 week until imposing RDI and biostimulants. Plants were then subjected to FI (no water deficiency treatment, field capacity $>70 \%$ ) and RDI (field capacity $<50 \%$ ) conditions until the end of each experiment. Plant agronomic performance, photosynthesis parameters, and WUE values were recorded weekly for 8 weeks and three individual experiments were carried out to assess the efficacy of biostimulants and irrigation treatments. Betaine $(0,50$, and $100 \mathrm{mM} /$ plant $)$ was foliage-treated every 2 weeks during Experiment 1, but chitin $(0,2$, and $4 \mathrm{~g} / \mathrm{kg})$ was applied to the soil at the beginning of Experiment 2. The optimal concentration of each chemical alone or in combination was then applied to the plants as Experiment 3. A factorial experiment design of two factors with different levels under a completely randomized arrangement was used in this investigation. Betaine (50 $\mathrm{mM})$ or chitin $(2 \mathrm{~g} / \mathrm{kg})$ treatments alone significantly elevated total fresh weight (63.03 or $124.07 \mathrm{~g} / \mathrm{plant})$, dry weight (18.00 or $22.34 \mathrm{~g} / \mathrm{plant}$ ), and cob weight ( 3.15 or $6.04 \mathrm{~g} / \mathrm{plant})$ and boosted the water-stress tolerance of the maize under RDI compared to controls. However, a combination treatment of $50 \mathrm{mM}$ betaine and $2 \mathrm{~g} / \mathrm{kg}$ chitin did not increase plant height, fresh shoot and root weights, dry cob weight, and total dry weight under RDI compared to controls. Soil-plant analysis development (SPAD) values $(>30)$ were effective in detecting plant growth performance and WUE values under RDI. These findings may have greater significance for farming in dry lands and offer information for further physiological studies on maize WUE and water stress tolerance.
\end{abstract}

Keywords: biostimulants; irrigation water requirement; photosynthesis; regulated deficit irrigation; water-saving agriculture; water stress 


\section{Introduction}

Irrigated agriculture currently delivers $40 \%$ of the world's food supply from just $20 \%$ of the world's cultivated land and provides crucial stability for global food security [1]. Using water sparingly can be an efficient way to maintain the sustainability of water resources, increase productivity, and produce yield stability in cropping systems, and thus help face the challenges of expanding human populations and its concomitant increased need for food. Irrigating plants according to their water status can minimize irrigation water waste. Many types of physiological stresses occur when plants encounter a water deficiency. Variability in maize yields due to soil water deficits is a function of the severity and timing of water deficits, available soil water at planting, effective rainfall, and irrigation [2]. Maize (Zea mays) growth performance and water use efficiency (WUE) are frequently limited by periods of water deficiency and soil water availability [3]. Soil water stress directly affects the soil water needed for photosynthesis and the maize plant's ability to efficiently convert physical resources into biological materials; i.e., plant height, leaf area index (LAI), reduced dry biomass, and grain yields [4-6]. A few days of severe water deficit in the vegetative stage of maize leads to a decrease in photosynthetically active leaf area (LA) in addition to inhibiting root growth and production [7]. Furthermore, the effects of WUE on maize yields and yield components have been discussed $[8,9]$.

Water shortages are responsible for the greatest crop losses around the world and are expected to worsen [8]. Various forms of deficit irrigation management have been suggested for achieving high yields with less water where agriculture is dependent on irrigation. Deficit irrigation maintains maize yield with less water and is especially important for buffering crops against yield losses due to end-of-season water shortfalls in water-limited environments and for maximizing water productivity [10]. Regulated deficit irrigation (RDI) is an efficient water-saving irrigation that tries to ensure an optimal crop water status for water stress and restricts irrigation in the most resistant crop [11-13]. It is particularly useful in areas where water supply is drastically limited during summer months because of severe drought or priorities for urban use [14]. RDI has a great positive impact on the growth, development, yield, and quality of crops, and usually improves WUE [15-17].

Strategies to mitigate losses due to inadequate water allow for the study and development of tolerant genotypes and application of biostimulants that induce water deficit tolerance in plants [18]. Plant biostimulants such as betaine and chitin are natural constituents and metabolites of plants and microorganisms that affect the crop itself and do not harm the environment due to their biodegradable and non-toxic nature [19]. They contain active substances of natural origin that can hasten plant growth and development and limit the effects of stress on plants. They also intensify water uptake and nutrient transport and stimulate photosynthesis [20]. Chitin is composed of repeating units of a saccharide monomer of $\mathrm{N}$-acetylglucosamine and is present in arthropod exoskeletons. Betaine is a fully $\mathrm{N}$-methyl-substituted derivative of glycine that is widely distributed in plants, animals, and microbes [21]. Betaine and chitin have several beneficial roles in different plant species under abiotic stress and can act as elicitors to address stress adaptation [22,23]. Studies of chitin and its derivatives (i.e., chitosan glycine) that induce resistance mechanisms under stress have been used in plants to confer resistance against water deficit, salinity, heat stress, and heavy metal toxicity [24,25]. Glycine betaine has multiple biological functions, including the maintenance of cellular water balance via osmotic adjustment [26,27]. However, there are no reports of betaine and chitin enhancing RDI in maize. The mechanisms of these two biostimulants' actions on the growth and physiological processes of RDI maize remain unknown. This study assessed the feasibility of using those two biostimulants to save water and increase maize yields. We hypothesized that betaine- and chitin-treated plants would be capable of inducing water deficit tolerance while increasing the yield and WUE of plants under RDI. The objectives of this study were to evaluate and compare the effects of optimal concentrations of betaine and chitin on agronomic performance, photosynthesis parameters, and WUE values of maize under RDI and full irrigation (FI) conditions. 


\section{Materials and Methods}

\subsection{Plant Material and Experimental Site}

Maize (Zea mays cv. 'White Pearl') seedlings grown in polyethylene plastic pots $(30 \mathrm{~cm}$ diameter $\times 26 \mathrm{~cm}$ height) were purchased from a local shop, Known-You Co. (Taipei, Taiwan). This variety is an $F_{1}$ hybrid that is one of the most popular of the waxy maizes grown in Taiwan in all seasons. The medium used was a commercial potting mix of peat moss, perlite, and vermiculite $(3: 1: 1 \mathrm{v} / \mathrm{v} / \mathrm{v})$ (Known-You Co., Taipei, Taiwan). Plantlets were acclimatized and grown in environment-controlled greenhouses at National Taiwan University (NTU, latitude $25.01^{\circ} \mathrm{N}$ ) for 1 week. All plants were fully watered in the evening, maintaining good soil moisture until RDI and biostimulants were imposed. From 102 plants, those of a relatively uniform size of were selected and randomly separated into different groups for the RDI and biostimulant experiments. The growth environment was controlled to a $12 / 12 \mathrm{~h}$ day/night photoperiod at $28 / 25^{\circ} \mathrm{C}$ with a relative humidity of $90 \%$ and $215 \mu \mathrm{mol} \cdot \mathrm{m}^{-2} \cdot \mathrm{s}^{-1}$ photosynthetic photon flux.

\subsection{Irrigation Treatments and Biostimulant Applications}

A week before the experiments started, each pot was irrigated until gravity water was released. Plants were then subjected to two irrigation levels differentiated by the amount of irrigation water applied over the 56 day experimental period that lasted from the early vegetative stage until fruit (cob) maturity. Irrigation treatments included a full irrigation treatment (FI, no water deficiency, field capacity $>70 \%$ ) as the control and regulated deficit irrigation treatment (RDI, field capacity $<50 \%$ ). Thirty minutes after irrigation, a soil moisture meter (WET Sensor, Type HH2, Delta-T Device, Cambridge, UK) was used to monitor and record the field capacity (converted from the reading of soil moisture content) of all treatments every day throughout the experiment.

Biostimulants were applied to each plant to study their responses to water stress. Three concentrations of aqueous solutions (dissolved in distilled deionized water) of betaine (B2629, Sigma, Ontario, CA, USA) at 0,50 , and $100 \mathrm{mM} /$ plant were sprayed onto plant leaves with a hand-held power sprayer until saturated. Betaine was foliage-treated every 2 weeks during Experiment 1 from 24 May to 23 July 2018. Moreover, three concentrations of chitin (C7170, Sigma, Ontario, CA, USA) at 0, 2, and $4 \mathrm{~g} / \mathrm{kg}$ were applied to the top $5 \mathrm{~cm}$ soil layer of each pot. Chitin was added to the soil once in the beginning of Experiment 2 that ran from 30 July to 30 September 2018. After investigating the differences in the two individual chemical treatments used in experiments 1 and 2, betaine $(50 \mathrm{mM})$ or chitin $(2 \mathrm{~g} / \mathrm{kg}$ ) treatments alone or in combination were also applied to the plants (Experiment 3, 9 October to 8 December 2018). All plants tested in Experiment 3 were subjected to the same experimental procedure as used during experiments 1 and 2. The concentrations of the chemical solutions were selected based on data from our preliminary study (data not shown). Plants without biostimulant treatment in the FI condition were considered controls to provide a basis for comparison with the effects of the biostimulants under FI and RDI. In each experiment, all plants from FI or RDI were harvested at the same time of day and used for yield components and WUE measurement.

\subsection{Data Collection and Analysis}

All plants were manually watered once a day in the late afternoon for the measurement of transpiration rate. Transpiration rate was determined by a portable photosynthesis system (GFS-3000, Walz, Germany) and calculated as how much water was absorbed in a confined space per unit time for the evapotranspiration rate. Six replicates of each irrigation treatment were arranged in a completely randomized design, and a total of 36 pots each in Experiment 1 and 2, and 30 pots in Experiment 3 were used. The agronomic performance, chlorophyll content, and WUE were measured using six randomly selected representative plants from each biostimulant treatment in each irrigation treatment. All analyses were performed weekly until the end of the 8 week experimental period: 
1. Leaf area (LA) measured by a portable LAI-3000C (LI-COR; Lincoln, NE, USA);

2. Plant height, measured as the height $(\mathrm{cm})$ above the soil with a Vernier caliper;

3. Fresh weight of shoots and roots, measured as green shoots and roots, and clipped at the soil surface to assess biomass accumulation;

4. Fresh and dry weights at harvest, the cobs from each plant being removed from stalks and weighed separately, followed by drying in an oven at $70{ }^{\circ} \mathrm{C}$ for 6 days;

5. Healthy, fully expanded mature leaves from the middle to upper portion of each plant were used to determine total chlorophyll (TC) content using a soil-plant analysis development (SPAD) analyzer (SPAD-502 Chlorophyll Meter, Konica Minolta, Tokyo, Japan); and

6. WUE parameters were calculated per treatment using the following formulae:

a. $\mathrm{WUE}_{\mathrm{i}}[28]$ was evaluated by calculating the net photosynthetic rate $\left(\mu \mathrm{mol} \cdot \mathrm{m}^{-2} \cdot \mathrm{s}^{-1}\right)$ divided by the transpiration rate $\left(\mathrm{mmol} \cdot \mathrm{m}^{-2} \cdot \mathrm{s}^{-1}\right)$. Both transpiration rate and net photosynthetic rate $\left(\mu \mathrm{mol} \cdot \mathrm{m}^{-2} \cdot \mathrm{s}^{-1}\right)$ of the leaves were determined using a portable photosynthesis system (GFS-3000, Walz, Germany) from 10:00 to 16:00 in a typical irrigation period. The second or third mature and expanded leaves with an LA of $3 \mathrm{~cm}^{2}$ were clipped by the clip-pad $\left(3 \mathrm{~cm}^{2}\right)$ from the GFS-3000 system. The measurement was conducted in the above-mentioned environmentally controlled room under $25^{\circ} \mathrm{C}$ and $1000 \mu \mathrm{mol} \cdot \mathrm{m}^{-2} \cdot \mathrm{s}^{-1}$.

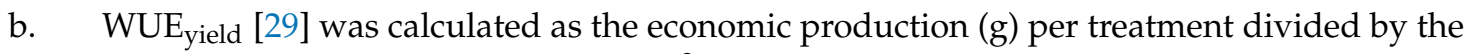
total irrigation water supplied $\left(\mathrm{kg} \cdot \mathrm{m}^{-3}\right)$.

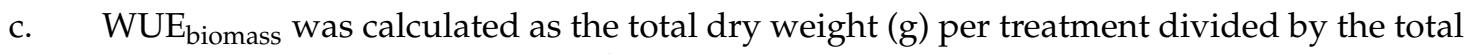
irrigation water supplied $\left(\mathrm{kg} \cdot \mathrm{m}^{-3}\right)$.

\subsection{Statistical Analysis}

The measurements of phenotypic traits were analyzed by a completely randomized analysis of variance (ANOVA) that compared the different irrigation and biostimulant treatments for each parameter. Two-factor ANOVA was used to analyze growth and yield data and photosynthetic parameters as well as the WUE data, with biostimulants and irrigation considered as two fixed effects. For significant values, means were separated by the least significant difference (LSD) test at $p \leq 0.05$ using Costat 6.29 (CoHort Software, Berkeley, CA, USA).

\section{Results and Discussion}

\subsection{Comparisons between Betaine-Treated and-Untreated Plants under FI and RDI (Experiment 1)}

Table 1 illustrates that applying betaine as a foliar spray alters morpho-physiological and yield responses of maize under RDI. The effects of betaine concentrations (B) on maize crop growth and yield under irrigation conditions (I) displayed significant differences $(p \leq 0.001,0.01$, and 0.05$)$ for the main effect and the interaction effect except for plant height, which showed non-significant differences in $B$ and IxB effects (Table 1). There were no significant differences in plant height, leaf area fresh shoot, cob weight, and total fresh and dry weight among the various betaine concentrations under FI treatment. However, in the RDI treatments, all agronomic characteristics gradually increased as foliage-treated betaine concentrations increased. We detected significantly higher growth trait values (except fresh root weight) in plants subjected to $100 \mathrm{mM}$ of betaine compared to $50 \mathrm{mM}$ of betaine treatment and controls (no betaine treatment). Most leaves appeared healthy and green when foliage-treated with $100 \mathrm{mM}$ of betaine under RDI compared to chitin-untreated plants, which were visually higher in leaf chlorosis than chitin-treated plants subjected to RDI (Figure 1A). Therefore, adding betaine under RDI promotes maize plant growth and yield, and it can be used for the rapid monitoring and early detection of water stress injury in the seedling stage and screening of individual plant that exhibit tolerance to water stress. 
Table 1. Effects of different concentrations of betaine on the agronomic performance of maize under full irrigation (FI) and regulated deficit irrigation (RDI).

\begin{tabular}{|c|c|c|c|c|c|c|c|c|c|c|c|}
\hline \multirow{2}{*}{$\begin{array}{l}\text { Irrigation } \\
\text { Treatment }\end{array}$} & \multirow{2}{*}{$\begin{array}{c}\text { Betaine } \\
\text { Concentration (mM) }\end{array}$} & \multicolumn{2}{|c|}{ Plant Height (cm) } & \multirow{2}{*}{$\begin{array}{l}\text { Leaf Area } \\
\left(\mathrm{cm}^{2}\right)\end{array}$} & \multicolumn{4}{|c|}{ Fresh Weight (g.per Plant) } & \multicolumn{2}{|c|}{ Dry Weight (g.per Plant) } & \multirow{2}{*}{$\begin{array}{c}\text { Total Water } \\
\text { Irrigation }(\mathrm{mL})\end{array}$} \\
\hline & & 0 Weeks & 8 Weeks & & Shoot & Root & Cob & Total & Cob & Total & \\
\hline FI & 0 & $22.80 \mathrm{a}$ & $208.80 \mathrm{ab}$ & 2036.10 a & $270.37 \mathrm{a}$ & $98.54 \mathrm{a}$ & $67.55 \mathrm{a}$ & $368.90 \mathrm{a}$ & $35.11 \mathrm{~b}$ & $111.64 \mathrm{a}$ & 23,700 \\
\hline FI & 50 & $21.93 \mathrm{a}$ & $209.98 \mathrm{ab}$ & 2077.26 a & $253.46 \mathrm{a}$ & $77.27 \mathrm{~b}$ & $73.10 \mathrm{a}$ & $330.73 \mathrm{ab}$ & $48.25 \mathrm{a}$ & $107.98 \mathrm{a}$ & 20,050 \\
\hline FI & 100 & $22.17 \mathrm{a}$ & $216.62 \mathrm{a}$ & $2182.33 \mathrm{a}$ & $241.96 \mathrm{a}$ & $97.39 \mathrm{a}$ & $81.58 \mathrm{a}$ & $339.34 \mathrm{ab}$ & $51.42 \mathrm{a}$ & $112.49 \mathrm{a}$ & 19,600 \\
\hline RDI & 0 & $22.42 \mathrm{a}$ & $143.20 \mathrm{c}$ & $948.91 \mathrm{c}$ & $90.88 \mathrm{c}$ & $30.20 \mathrm{~d}$ & $0.00 \mathrm{c}$ & $121.08 \mathrm{~d}$ & $0.00 \mathrm{~d}$ & $38.83 \mathrm{c}$ & 8050 \\
\hline RDI & 50 & $23.33 \mathrm{a}$ & $144.93 \mathrm{c}$ & $1619.77 \mathrm{~b}$ & $180.76 \mathrm{~b}$ & $53.40 \mathrm{c}$ & $21.04 \mathrm{~b}$ & $234.16 \mathrm{c}$ & $11.65 \mathrm{c}$ & $44.74 \mathrm{c}$ & 5200 \\
\hline RDI & 100 & $22.90 \mathrm{a}$ & $179.72 \mathrm{~b}$ & 2068.90 a & 238.79 a & $69.87 \mathrm{bc}$ & $74.36 \mathrm{a}$ & $308.66 \mathrm{~b}$ & $38.78 \mathrm{~b}$ & $84.65 \mathrm{~b}$ & 6400 \\
\hline \multicolumn{12}{|c|}{ Source of variation } \\
\hline \multicolumn{2}{|c|}{ Irrigation treatments (I) } & & $* * *$ & $* * *$ & $* * *$ & $* * *$ & $* * *$ & $* * *$ & $* * *$ & $* * *$ & \\
\hline \multicolumn{2}{|c|}{ Betaine concentration (B) } & & ns & $* * *$ & $* *$ & * & $* * *$ & $* *$ & $* * *$ & * & \\
\hline \multicolumn{2}{|r|}{$\mathrm{I} \times \mathrm{B}$} & & ns & $* *$ & $* * *$ & * & $* * *$ & $* * *$ & * & * & \\
\hline
\end{tabular}

Data were recorded and calculated after 8 weeks of irrigation and betaine treatments from six replicates. Means in the same column within treatments followed by different letters are significantly different at $p \leq 0.05$ by least significant difference (LSD). Each treatment is assumed to be dependent on the other. ANOVA results of the main effects of irrigation (I), betaine $(\mathrm{B})$, and their interaction effect $(\mathrm{I} \times \mathrm{B})$ on the agronomic performance of maize are shown as ns, ${ }^{*}, * *$, and ${ }^{* * *}$ as non-significant and significant at $p \leq 0.05,0.01$, or 0.001 , respectively.

Table 2. Effects of different concentrations of betaine on the photosynthesis and water use efficiency (WUE $\mathrm{i}_{\mathrm{i}}$, WUE $\mathrm{E}_{\mathrm{yield}}$, WUE $\mathrm{biomass}_{\text {s }}$ ) of maize under full irrigation (FI) and regulated deficit irrigation (RDI).

\begin{tabular}{|c|c|c|c|c|c|c|c|c|c|}
\hline \multirow{2}{*}{$\begin{array}{l}\text { Irrigation } \\
\text { Treatment }\end{array}$} & \multirow{2}{*}{$\begin{array}{c}\text { Betaine } \\
\text { Concentration } \\
(\mathrm{mM})\end{array}$} & \multicolumn{3}{|c|}{0 Weeks } & \multicolumn{3}{|c|}{8 Weeks } & \multirow{2}{*}{$\begin{array}{l}\text { WUE }{ }_{\text {yield }} \\
\left(\mathbf{k g} \cdot \mathbf{m}^{-3}\right)\end{array}$} & \multirow{2}{*}{$\begin{array}{l}\text { WUE }_{\text {biomass }} \\
\left(\mathbf{k g} \cdot \mathrm{m}^{-3}\right)\end{array}$} \\
\hline & & $\begin{array}{c}\text { Transpiration } \\
\left(\mu \mathrm{mol} \mathrm{m}{ }^{-2} \cdot \mathrm{s}^{-1}\right)\end{array}$ & $\begin{array}{l}\text { Net Photosynthesis } \\
\left(\mathrm{mmol} \mathrm{m}^{-2} \cdot \mathrm{s}^{-1}\right)\end{array}$ & $\begin{array}{c}\text { WUEi } \\
\left(\mathrm{mmol} \mathrm{CO}_{2} \cdot \mathrm{mol}^{-1} \mathrm{H}_{2} \mathrm{O}\right)\end{array}$ & $\begin{array}{c}\text { Transpiration } \\
\left(\mu \mathrm{mol} \mathrm{m}^{-2} \cdot \mathrm{s}^{-1}\right)\end{array}$ & $\begin{array}{l}\text { Net Photosynthesis } \\
\left(\mathrm{mmol} \mathrm{m}^{-2} \cdot \mathrm{s}^{-1}\right)\end{array}$ & $\begin{array}{c}\text { WUEi } \\
\left(\mathrm{mmol} \mathrm{CO}{ }_{2} \cdot \mathrm{mol}^{-1} \mathrm{H}_{2} \mathrm{O}\right)\end{array}$ & & \\
\hline FI & 0 & $0.98 \mathrm{a}$ & $14.83 \mathrm{a}$ & $16.25 \mathrm{a}$ & $0.96 \mathrm{a}$ & $12.17 \mathrm{~b}$ & $15.78 \mathrm{c}$ & $2.85 \mathrm{c}$ & $1.48 \mathrm{~b}$ \\
\hline FI & 50 & $1.05 \mathrm{a}$ & $15.39 \mathrm{a}$ & $16.85 \mathrm{a}$ & $0.80 \mathrm{ab}$ & $15.97 \mathrm{ab}$ & $22.55 \mathrm{~b}$ & $3.65 \mathrm{bc}$ & $2.41 \mathrm{~b}$ \\
\hline FI & 100 & $0.93 \mathrm{a}$ & $14.77 \mathrm{a}$ & $18.78 \mathrm{a}$ & $0.82 \mathrm{ab}$ & $17.01 \mathrm{a}$ & $24.93 \mathrm{~b}$ & $4.16 \mathrm{~b}$ & $2.62 \mathrm{~b}$ \\
\hline RDI & 0 & $1.10 \mathrm{a}$ & $15.09 \mathrm{a}$ & $14.28 \mathrm{a}$ & $0.45 \mathrm{ab}$ & $9.41 \mathrm{c}$ & $22.27 b$ & $0.00 \mathrm{~d}$ & $0.00 \mathrm{c}$ \\
\hline RDI & 50 & $1.06 \mathrm{a}$ & $14.82 \mathrm{a}$ & $15.80 \mathrm{a}$ & $0.52 \mathrm{~b}$ & $15.09 \mathrm{ab}$ & $46.21 \mathrm{a}$ & $4.05 \mathrm{~b}$ & $2.24 \mathrm{~b}$ \\
\hline RDI & 100 & $1.03 \mathrm{a}$ & $14.90 \mathrm{a}$ & $14.71 \mathrm{a}$ & $0.74 \mathrm{ab}$ & $16.18 \mathrm{ab}$ & $28.16 \mathrm{~b}$ & $11.62 \mathrm{a}$ & $6.06 \mathrm{a}$ \\
\hline \multicolumn{10}{|c|}{ Source of variation } \\
\hline \multirow{2}{*}{\multicolumn{2}{|c|}{$\begin{array}{l}\text { Irrigation treatment (I) } \\
\text { betaine concentration (B) }\end{array}$}} & & & & * & ns & * & * & * \\
\hline & & & & & ns & $* *$ & * & * & * \\
\hline \multicolumn{2}{|c|}{$\mathrm{I} \times \mathrm{B}$} & & & & ns & $\mathrm{ns}$ & ns & ns & ns \\
\hline
\end{tabular}

Data were recorded and calculated after 8 weeks of irrigation and betaine treatments from six replicates. Means in the same column within treatments followed by different letters are significantly different at $p \leq 0.05$ by least significant difference (LSD). Each treatment is assumed to be dependent on the other. ANOVA results of the main effects of irrigation (I), betaine (B), and their interaction effect $(\mathrm{I} \times \mathrm{B})$ on the photosynthesis and WUE values of maize are shown as ns, ${ }^{*}, * *$ as non-significant and significant at $p \leq 0.05,0.01$, respectively. 


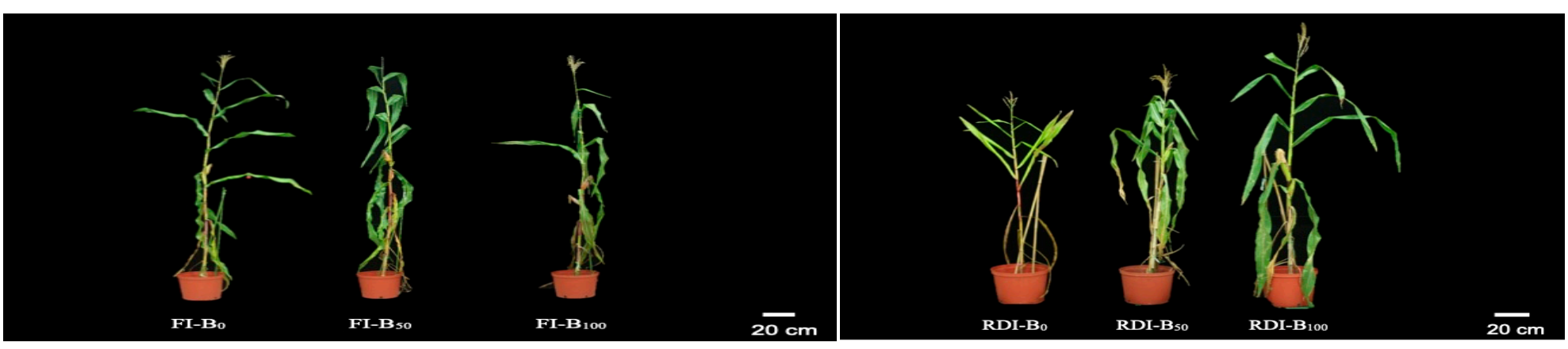

(A)
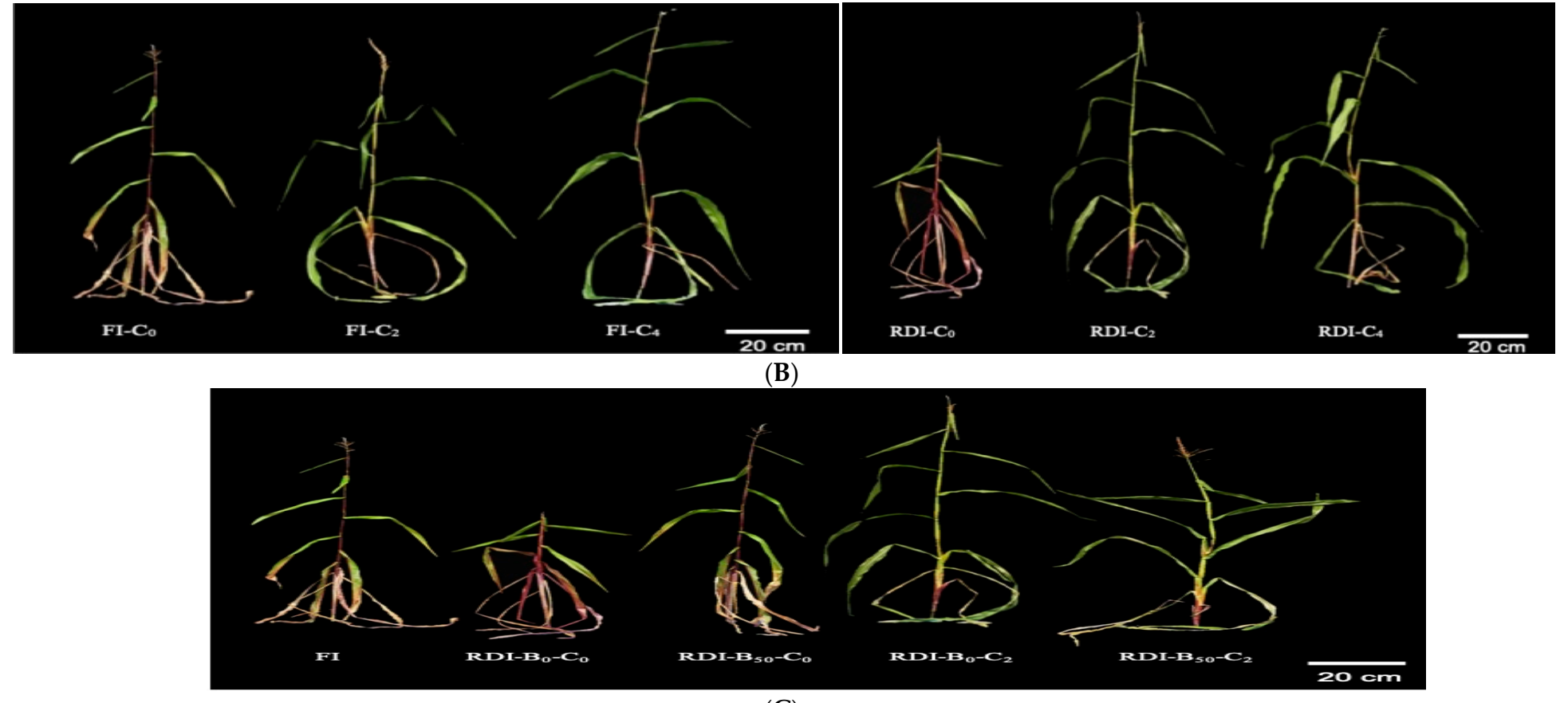

(C)

Figure 1. Effects of different concentrations of betaine (A), chitin (B), and betaine and chitin (C) on the morphological appearance of maize 'White Pearl' plants under full irrigation (FI) and regulated deficit irrigation (RDI). Betaine $(0,50$, and $100 \mathrm{mM} / \mathrm{plant})$ was foliage-treated, but chitin $(0,2$, and $4 \mathrm{~g} / \mathrm{kg})$ was applied to the soil. Bar indicates $20 \mathrm{~cm}$. 
There were significant differences in all photosynthesis and WUE values for the main effects, except for transpiration in B effects and net photosynthesis in I effects (Table 2). Moreover, interaction effects did not significantly affect any of the measurements. There were no marked differences in transpiration after the 8 weeks under FI $\left(0.80 \sim 0.96 \mu \mathrm{mol} \cdot \mathrm{m}^{-2} \cdot \mathrm{s}^{-1}\right)$ and RDI $\left(0.45 \sim 0.74 \mu \mathrm{mol} \cdot \mathrm{m}^{-2} \cdot \mathrm{s}^{-1}\right)$ treatments compared to controls. However, all $100 \mathrm{mM}$ betaine treatments displayed significantly higher net photosynthesis $\left(16.18 \sim 17.01 \mathrm{mmol} \cdot \mathrm{m}^{-2} \cdot \mathrm{s}^{-1}\right)$ values compared to controls $\left(12.17 \mathrm{mmol} \cdot \mathrm{m}^{-2} \cdot \mathrm{s}^{-1}\right)$. WUE $E_{i}$ under RDI with $50 \mathrm{mM}$ of betaine treatment $\left(46.21 \mathrm{mmol} \mathrm{CO} \cdot \mathrm{mol}^{-1} \mathrm{H}_{2} \mathrm{O}\right)$ was significantly higher than in other treatments and controls, ranging from 28.16 to $15.78 \mathrm{mmol} \mathrm{CO}_{2} \cdot \mathrm{mol}^{-1} \mathrm{H}_{2} \mathrm{O}$. There were no marked differences in WUE yield $\left(2.85 \sim 4.16 \mathrm{~kg} \cdot \mathrm{m}^{-3}\right)$ and $W U E_{\text {biomass }}(1.48 \sim 2.62 \mathrm{~kg} \cdot \mathrm{mL})$ among the different betaine treatments under FI. Nevertheless, significantly higher WUE ${ }_{\text {yield }}\left(11.62 \mathrm{~kg} \cdot \mathrm{m}^{-3}\right)$ and $W_{\text {UEiomass }}\left(6.06 \mathrm{~kg} \cdot \mathrm{m}^{-3}\right)$ values were detected in $100 \mathrm{mM}$ betaine treatments under RDI compared to other treatments. In general, net photosynthesis and WUE values increased with increasing betaine concentrations and decreasing water application, except for WUEi in the $50 \mathrm{mM}$ betaine treatment under RDI.

The total amount of water applied to maize from the first day ( 0 weeks) up to the 56th day (8 weeks) under FI was 19,600 23,700 mL. Compared to this amount, RDI received remarkably less irrigation water, ranging from 5200 $8050 \mathrm{~mL}$ (Figure S1). Total water irrigation decreased under RDI, indicating that maize suffered from water stress injury. Betaine was applied biweekly four times after planting, and because betaine application to RDI treated plants improved plant water status, it is reasonable to expect that this in turn led to favorable effects on the photosynthesis and WUE values. This implies that betaine treatment increased yield-related traits, photosynthesis, and WUE values under RDI and boosted water stress tolerance.

Deficit irrigation is correctly applied only thorough an understanding of the yield response to water. The capacity of plants to absorb nutrients is typically weak when anti-transpirants are sprayed onto leaves under water deficit conditions because of the resulting limited transpiration pull [30]. Exogenous betaine significantly alleviates drought and salt stress-induced growth inhibition in rice [31] and barley [32]. Glycine betaine-treated leaves significantly increase the ability of the antioxidant defense system to resist abiotic stresses in different plant species [33-36]. Furthermore, plants can improve their capacity for osmotic adjustment by increasing glycine betaine accumulation under drought stress [37]. The foliar application of glycine betaine under drought conditions regulates the turgor pressure of guard cells by increasing the bound water content in cells regulating stomatal opening and closing, thus increasing chlorophyll content, stomatal conductance, and photosystem-II efficiency and stabilizing total carotenoids in pepper [38] and rice [39]. Spraying 150 ppm glycine betaine on maize plants under drought stress improves chlorophyll content, plant height, and yield [40]. When we applied $100 \mathrm{mM}$ betaine under a soil water deficit, plants increased their transpiration capacity without affecting aboveground growth. It is not clear how betaine treatment improves the water status of leaves during water stress, but it might be that water uptake efficiency is improved or that water loss is retarded, or both. Betaine spraying could favorably activate leaf signaling to reduce water loss through transpiration, maintain a favorable level of transpiration, and facilitating the absorption of water and nutrients from soil while maintaining a higher level of photosynthesis. Reducing luxury transpiration and increasing net photosynthesis by applying betaine provides an opportunity for relieving the adverse effects of RDI on maize plants and improving their WUE when transpiration frequently exceeds water uptake. This contributes to reducing water loss and maintaining proper water consumption, thus saving agricultural water resources in dry-land areas.

\subsection{Comparisons between Chitin-Treated and-Untreated Plants Subjected to FI and RDI (Experiment 2)}

Tables 3 and 4 present the effects of chitin treatments on agronomic performance, photosynthesis, and WUE values of maize under FI and RDI. All measurements appeared to differ significantly in terms of chitin's (C) main effect. Both plant height and leaf area showed significant differences in all effects $(\mathrm{I}, \mathrm{C}$, and $\mathrm{I} \times \mathrm{C}$ ). Interestingly, under FI, there was an increasing trend in all measurements in 
all plants when chitin application increased from 0 to $4 \mathrm{~g} / \mathrm{kg}$. However, when 2 and $4 \mathrm{~g} / \mathrm{kg}$ of chitin were applied to each pot under RDI, the plants exhibited significantly higher levels in all agronomic characteristics compared to the no-chitin treatment. The total amount of water applied under FI and RDI was $9000 \sim 13,500 \mathrm{~mL}$ and $2050 \sim 3150 \mathrm{~mL}$, respectively. These observations demonstrated that plants were highly regulated by chitin and all measured traits drastically elevated; thus, treating maize with chitin can mitigate the effects of drought stress.

There were significant differences in photosynthesis and WUE values among chitin concentrations, with 2 and $4 \mathrm{~g} / \mathrm{kg}$ chitin applications showing significantly higher photosynthesis and WUE values under all irrigation conditions, except transpiration under the FI condition, in comparison to controls. Interestingly, all chitin-treated plants displayed significantly higher (36.02 31.45) total chlorophyll (TC) content than chitin-untreated plants (17.27 10.72) in all irrigation treatments. We also assessed the effect of chitin treatment on plant growth under RDI. Figure 1B depicts epinasty and senescence in the lower leaves of chitin-untreated plants under RDI after 8 weeks of stress; however, most leaves looked green and healthy under chitin applications and RDI conditions. Water stress had a harmful effect during RDI, the degree of chlorosis being related to a reduction in leaf TC content. These observations imply that chitin application might reduce or delay water stress, thereby allowing plants to survive and function during stress. This ability perhaps can be attributed to an avoidance of water stress, as indicated by the higher yield components, photosynthesis parameters, and WUE values in chitin-treated plants compared to chitin-untreated plants during RDI conditions. It is also possible that chitin has the capacity to absorb water, which in turn increases the water holding capacity of the soil and the water available for the plant to use, i.e., chitin increases soil moisture [41].

The application of chitosan leads to increases in plant height, number of shoot branches, number of leaves, leaf area, biomass, and grain yield in maize [42]. Moreover, chitosan treatment in white clover alleviates drought stress and increases the production of stress protective metabolites [43]. Chitosan application under drought stress increases sweet basil growth [44]. Treatment with chitin oligosaccharides increases the photosynthesis level of maize [45]. Furthermore, water stress decreases pigment content and photosynthesis parameters in maize, but the application of chitosan and derivatives increases them [46]. The application of a mixture of chitosan derivatives also induces a tolerance to water deficit in maize, improving the antioxidant system and increasing photosynthesis and grain yield [47]. Chitin features prominent biochemical similarities in plant cell walls, including neutrally charged linear polysaccharide chains that provide mechanical, physical, and structural stability [48].

Total chlorophyll (TC) value has been widely examined in a number of plants to determine injury or tolerance to various environmental stresses, including drought, chilling, heat, and radiation [49]. Typically, stressful conditions reduce TC levels, so TC values from chlorophyll meter readings can be used as a parameter of drought tolerance. The SPAD assesses TC contents and photosynthetic capacity [50]. In this study, RDI affected maize yield components, photosynthesis parameters, and WUE values. Plants with higher SPAD, net photosynthesis, and WUE values also had higher cob and total dry weights. When SPAD values were $>31$ in the chitin-treated groups, it became useful for measuring WUE when developing indices for nondestructive chlorophyll estimation. This means that many hundreds of individual plants can be screened per day, providing many opportunities to discover individuals that manifest yield indicators and exhibit greater photosynthesis and WUE. However, no studies have been conducted on the effects of chitin treatments on yield, photosynthesis, and WUE values of maize under RDI. In addition, because of the low cost of chitin, improvements in these parameters under RDI conditions will reduce the cost per plant or per acre of new plantings.

\subsection{Effects of Betaine and Chitin Treatments on Plant Physiology and Morphology under FI and RDI (Experiment 3)}

Tables 5 and 6 summarize the impact of chitin and betaine on agronomic performance, photosynthesis, and WUE values of maize under FI and RDI conditions. All of the measurements appear to significantly differ in the main effect $(\mathrm{I})$ and interaction effect $(\mathrm{B} \times \mathrm{C})$, except for fresh root weight and transpiration. Thus, the agronomic traits of the plants responded differently to betaine and chitin treatments alone 
or mixtures under RDI. Compared to no chemical treatments, the application of betaine $(50 \mathrm{mM})$ or chitin $(2 \mathrm{~g} / \mathrm{kg})$ alone to plants under RDI had relatively higher growth, yield, photosynthesis parameters, and WUE values, except for plant height, fresh root weight, and transpiration. Notably, RDI combined with $2 \mathrm{~g} / \mathrm{kg}$ of chitin produced significantly higher plant height, shoot fresh weight, cob weight, total fresh and dry weights, TC level, and net photosynthesis compared to the other treatments. The SPAD value (31.47) in leaves under $2 \mathrm{~g} / \mathrm{kg}$ chitin treatment was significantly higher in RDI compared to other treatments, ranging from 26.23 10.72. Moreover, the application of $50 \mathrm{mM}$ betaine with RDI also improved the 'White Pearl' maize yield and WUE as well compared to control. Table 1 has shown that 50 and $100 \mathrm{mM}$ betaine treatments under RDI resulted in relatively higher yield, photosynthesis, and WUE values compared to untreated plants. Therefore, RDI with WUE can be used in a nondestructive estimation of yield and biomass when screening for water stress tolerant plants. Tables 5 and 6 reveal that treatment with a combination of betaine and chitin did not exhibit a synergistic optimum on yield, photosynthesis, and WUE values under RDI. However, using chitin alone on plants under RDI significantly increased yield-related traits compared to plants without chitin treatment and controls, and thus can be applied on a commercial scale for saving water without sacrificing yield. Compared to FI (13,503 mL), RDI plants received remarkably less irrigation water, ranging from 1800 3148 $\mathrm{mL}$. Treatment with $2 \mathrm{~g} / \mathrm{kg}$ chitin per plant in RDI conditions increases photosynthesis and WUE values in maize, which offers insight into the mechanism of its action for water saving advances in the future.

Figure 1C illustrates that chlorosis in most RDI and chitin-untreated plants was visibly greater than in chitin-treated plants subjected to RDI. Similarly, RDI control plants had significantly lower TC content along with the characteristic visual symptoms. In addition, there was a gradual inhibition in light-induced chlorophyll accumulation over the time of the RDI treatment (data not shown). Therefore, biostimulators can be applied to plants when SPAD values reach 31. Different biostimulators acted differently under RDI treatment; however, each biostimulator is not necessarily equally significant in protecting against water stress. The impacts of changing plant physiology and morphology on water stress tolerance and plant health were affected by betaine and chitin application.

The results can be applied for improving the water stress tolerance of maize plants, developing management practices for field cultivation, reducing energy consumption, and enhancing cultivation when water resources are limited. A better understanding of the growing characteristics of these plants would also aid in their effective cultivation on arid lands or in extreme climates. In addition, the cost-effectiveness of betaine $(50 \mathrm{mM} / \mathrm{plant})$ and chitin $(2 \mathrm{~g} / \mathrm{kg}$ soil) related to yields and reduction of water use would be 0.017 and 0.17 US dollars per plant, respectively. Increasing yield and WUE from different biostimulants under RDI provided plants with increased water stress tolerance, playing a key role in providing better adaptation to water stress. The effects of water stress on maize can be lessened by treatment with betaine and chitin because these chemicals may protect cell membranes from the adverse effects of water stress. Betaine and chitin act at a convergence point for integrating different signals, minimizing cell damage caused by water deficits, and improving the physiological and biochemical condition of plants, thus making plants more tolerant to aridity. Further transcriptomic and proteomic studies of water-stressed responsive genes and proteins need to be identified to provide better usage of betaine and chitin in water stress management. 
Table 3. Effects of different concentrations of chitin on the agronomic performance of maize under full irrigation (FI) and regulated deficit irrigation (RDI).

\begin{tabular}{|c|c|c|c|c|c|c|c|c|c|c|c|}
\hline \multirow{2}{*}{$\begin{array}{l}\text { Irrigation } \\
\text { Treatment }\end{array}$} & \multirow{2}{*}{$\begin{array}{c}\text { Chitin Concentration } \\
(\mathrm{g} / \mathrm{kg})\end{array}$} & \multicolumn{2}{|c|}{ Plant Height (cm) } & \multirow{2}{*}{$\begin{array}{l}\text { Leaf Area } \\
\left(\mathrm{cm}^{2}\right)\end{array}$} & \multicolumn{4}{|c|}{ Fresh Weight (g.per Plant) } & \multicolumn{2}{|c|}{ Dry Weight (g.per Plant) } & \multirow{2}{*}{$\begin{array}{l}\text { Total Water } \\
\text { Irrigation }(\mathrm{mL})\end{array}$} \\
\hline & & 0 Weeks & 8 Weeks & & Shoot & Root & Cob & Total & Cob & Total & \\
\hline FI & 0 & $16.33 \mathrm{a}$ & $94.63 \mathrm{c}$ & $530.62 \mathrm{c}$ & $47.16 \mathrm{~b}$ & $7.97 \mathrm{~b}$ & $8.49 \mathrm{~b}$ & $63.63 \mathrm{~b}$ & $2.38 \mathrm{~b}$ & $15.26 \mathrm{~b}$ & 13,500 \\
\hline FI & 2 & $16.13 \mathrm{a}$ & $95.20 \mathrm{c}$ & $827.49 \mathrm{~b}$ & $78.35 a$ & $10.44 \mathrm{a}$ & 24.27 a & $113.06 \mathrm{a}$ & $4.63 \mathrm{a}$ & $17.03 \mathrm{~b}$ & 9000 \\
\hline FI & 4 & $16.01 \mathrm{a}$ & $101.02 \mathrm{~b}$ & $1001.47 \mathrm{a}$ & $87.19 \mathrm{a}$ & $12.07 \mathrm{a}$ & $29.37 \mathrm{a}$ & $128.63 \mathrm{a}$ & $5.38 \mathrm{a}$ & 21.83 a & 9300 \\
\hline RDI & 0 & $16.00 \mathrm{a}$ & $48.72 \mathrm{~d}$ & $190.53 \mathrm{~d}$ & $22.00 \mathrm{c}$ & $3.03 \mathrm{c}$ & $1.72 \mathrm{c}$ & $26.75 c$ & $0.55 \mathrm{c}$ & $6.25 c$ & 3150 \\
\hline RDI & 2 & $16.35 \mathrm{a}$ & $128.29 a$ & $1057.29 \mathrm{a}$ & $86.27 \mathrm{a}$ & $10.09 \mathrm{a}$ & $27.81 \mathrm{a}$ & $124.08 \mathrm{a}$ & $6.07 \mathrm{a}$ & $22.30 \mathrm{a}$ & 2050 \\
\hline RDI & 4 & $16.67 \mathrm{a}$ & $114.17 \mathrm{~b}$ & 1046.13 a & $81.06 \mathrm{a}$ & $10.89 a$ & $24.20 \mathrm{a}$ & $116.15 \mathrm{a}$ & $5.73 \mathrm{a}$ & $20.94 \mathrm{a}$ & 2350 \\
\hline \multicolumn{12}{|c|}{ Source of variation } \\
\hline \multicolumn{2}{|c|}{ Irrigation treatment $(\mathrm{I})$} & & * & $*$ & ns & ns & ns & ns & ns & ns & \\
\hline \multicolumn{2}{|c|}{ Chitin concentration (C) } & & $* * *$ & $* * *$ & $* * *$ & * & $* * *$ & $* * *$ & $* * *$ & $* * *$ & \\
\hline \multicolumn{2}{|r|}{$\mathrm{I} \times \mathrm{C}$} & & $* * *$ & $* *$ & ns & ns & ns & ns & ns & $* * *$ & \\
\hline
\end{tabular}

Data were recorded and calculated after 8 weeks of irrigation and chitin treatments from six replicates. Means in the same column within treatments followed by different letters are significantly different at $p \leq 0.05$ by LSD. Each treatment is assumed to be dependent on the other. SPAD, soil-plant analysis development, is the chlorophyll meter reading. ANOVA results of the main effects of irrigation (I), chitin $(\mathrm{C})$, and their interaction effect $(\mathrm{I} \times \mathrm{C})$ on the agronomic performance of maize are shown as ns, ${ }^{* * *}$, and $* * *$ as non-significant and significant at $p \leq 0.055,0.01$, or 0.001 , respectively.

Table 4. Effects of different concentrations of chitin on the photosynthesis and water use efficiency (WUE $\left.\mathrm{i}_{\mathrm{i}}, \mathrm{WUE}_{\mathrm{yield}}, \mathrm{WUE}_{\mathrm{biomass}}\right)$ of maize under full irrigation (FI) and regulated deficit irrigation (RDI).

\begin{tabular}{|c|c|c|c|c|c|c|c|}
\hline $\begin{array}{l}\text { Irrigation } \\
\text { Treatments }\end{array}$ & $\begin{array}{c}\text { Chitin Concentration } \\
(\mathrm{g} / \mathrm{kg})\end{array}$ & SPAD Value & $\begin{array}{c}\text { Transpiration } \\
\left(\mu \mathrm{mol} \mathrm{m}^{-2} \cdot \mathrm{s}^{-1}\right)\end{array}$ & $\begin{array}{l}\text { Net Photosynthesis } \\
\left(\mathrm{mmol} \mathrm{m}^{-2} \cdot \mathrm{s}^{-1}\right)\end{array}$ & $\begin{array}{c}\mathrm{WUE}_{\mathrm{i}} \\
\left(\mathrm{mmol} \mathrm{CO}{ }_{2} \cdot \mathrm{mol}^{-1} \mathrm{H}_{2} \mathrm{O}\right)\end{array}$ & $\begin{array}{l}\text { WUE }_{\text {yield }} \\
\left(\mathrm{kg} \mathrm{m}^{-3}\right)\end{array}$ & $\begin{array}{l}\text { WUE } \\
\left(\mathrm{kg} \mathrm{m}_{\text {biomass }}^{-3}\right)\end{array}$ \\
\hline FI & 0 & $17.27 \mathrm{~b}$ & $1.05 \mathrm{a}$ & $10.63 \mathrm{~b}$ & $10.09 \mathrm{c}$ & $0.63 \mathrm{c}$ & $1.13 \mathrm{~b}$ \\
\hline FI & 2 & $35.53 \mathrm{a}$ & $1.13 \mathrm{a}$ & $14.43 \mathrm{ab}$ & $12.96 \mathrm{~b}$ & $2.70 \mathrm{~b}$ & $1.89 \mathrm{~b}$ \\
\hline FI & 4 & $36.02 \mathrm{a}$ & $1.21 \mathrm{a}$ & $16.85 \mathrm{a}$ & $14.05 \mathrm{ab}$ & $3.16 \mathrm{~b}$ & $2.35 \mathrm{~b}$ \\
\hline RDI & 0 & $10.72 \mathrm{c}$ & $0.55 \mathrm{~b}$ & $3.80 \mathrm{c}$ & $7.97 \mathrm{~d}$ & $0.55 \mathrm{c}$ & $1.98 \mathrm{~b}$ \\
\hline RDI & 2 & $31.45 \mathrm{a}$ & $0.98 \mathrm{a}$ & $16.19 \mathrm{a}$ & $16.85 \mathrm{a}$ & $13.56 \mathrm{a}$ & $10.88 \mathrm{a}$ \\
\hline RDI & 4 & $33.95 \mathrm{a}$ & $1.08 \mathrm{a}$ & $15.49 \mathrm{a}$ & $14.46 \mathrm{ab}$ & $10.30 \mathrm{a}$ & $8.91 \mathrm{a}$ \\
\hline \multicolumn{8}{|c|}{ Source of variation } \\
\hline \multirow{2}{*}{\multicolumn{2}{|c|}{$\begin{array}{l}\text { Irrigation treatment (I) } \\
\text { chitin concentration }(\mathrm{C})\end{array}$}} & * & ns & ns & ns & ns & ns \\
\hline & & $* * *$ & ** & $* * *$ & $* * *$ & * & * \\
\hline \multicolumn{2}{|r|}{$\mathrm{I} \times \mathrm{C}$} & ns & ns & $*$ & * & ns & ns \\
\hline
\end{tabular}

Data were recorded and calculated after 8 weeks of irrigation and chitin treatments from six replicates. Means in the same column within treatments followed by different letters are significantly different at $p \leq 0.05$ by LSD. Each treatment is assumed to be dependent on the other. SPAD, soil-plant analysis development, is the chlorophyll meter reading. ANOVA results of the main effects of irrigation (I), chitin $(\mathrm{C})$, and their interaction effect $(\mathrm{I} \times \mathrm{C})$ on the photosynthesis and water use efficiency of maize are shown as ns, ${ }^{* * *}$, and ${ }^{* * *}$ as non-significant and significant at $p \leq 0.055,0.01$, or 0.001 , respectively. 
Table 5. Effects of different concentrations of betaine and chitin on the agronomic performance of maize under full irrigation (FI) and regulated deficit irrigation (RDI).

\begin{tabular}{|c|c|c|c|c|c|c|c|c|c|c|c|}
\hline \multirow{2}{*}{$\begin{array}{l}\text { Irrigation } \\
\text { Treatment }\end{array}$} & \multirow{2}{*}{$\begin{array}{l}\text { Betaine } \\
\text { (mM) }\end{array}$} & \multirow{2}{*}{$\begin{array}{l}\text { Chitin } \\
\text { (g/kg) }\end{array}$} & \multicolumn{2}{|c|}{ Plant Height (cm) } & \multirow{2}{*}{$\begin{array}{l}\text { Leaf Area } \\
\left(\mathrm{cm}^{2}\right)\end{array}$} & \multicolumn{3}{|c|}{ Fresh Weight (g.per Plant) } & \multicolumn{3}{|c|}{ Dry Weight (g.per Plant) } \\
\hline & & & 0 Weeks & 8 Weeks & & Shoot & Root & Cob & Total & Cob & Total \\
\hline FI & 0 & 0 & $16.32 \mathrm{a}$ & $94.65 \mathrm{~b}$ & $530.61 \mathrm{c}$ & $47.14 \mathrm{~b}$ & $7.99 \mathrm{ab}$ & $8.46 \mathrm{c}$ & $63.69 \mathrm{c}$ & $2.36 \mathrm{~b}$ & 15.24 \\
\hline RDI & 0 & 0 & $16.02 \mathrm{a}$ & $48.70 \mathrm{c}$ & $190.55 \mathrm{~d}$ & $22.03 \mathrm{c}$ & $3.04 \mathrm{c}$ & $1.70 \mathrm{~d}$ & $26.74 \mathrm{~d}$ & $0.57 \mathrm{c}$ & 6.23 \\
\hline RDI & 50 & 0 & $16.35 \mathrm{a}$ & $88.80 \mathrm{~b}$ & $561.63 \mathrm{~b}$ & $48.49 \mathrm{~b}$ & $5.89 \mathrm{bc}$ & $8.71 \mathrm{c}$ & $63.03 c$ & $3.15 \mathrm{~b}$ & 18.00 c \\
\hline RDI & 0 & 2 & $16.30 \mathrm{a}$ & $128.25 \mathrm{a}$ & $1057.26 \mathrm{a}$ & $86.26 \mathrm{a}$ & $10.06 \mathrm{a}$ & $27.80 \mathrm{a}$ & $124.07 \mathrm{a}$ & $6.04 \mathrm{a}$ & 22.34 \\
\hline RDI & 50 & 2 & $16.27 \mathrm{a}$ & 84.58 b & $867.46 \mathrm{ab}$ & $59.13 \mathrm{~b}$ & $6.55 \mathrm{~b}$ & $17.03 \mathrm{~b}$ & $82.71 \mathrm{~b}$ & $3.60 \mathrm{~b}$ & 15.51 \\
\hline \multicolumn{12}{|c|}{ Source of variation } \\
\hline \multicolumn{3}{|c|}{ Betaine concentration (B) } & & ns & * & ns & ns & ns & ns & ns & ns \\
\hline \multirow{2}{*}{\multicolumn{3}{|c|}{ Chitin concentration $(\mathrm{C})$}} & & $* *$ & $* * *$ & $* * *$ & ns & $* * *$ & $* * *$ & $* *$ & $*$ \\
\hline & & & & $* *$ & * & * & ns & $* * *$ & $* *$ & $* *$ & $* *$ \\
\hline
\end{tabular}

Data were recorded and calculated after 8 weeks of irrigation and chemical treatments from six replicates. Means in the same column within treatments followed by different letters are significantly different at $p \leq 0.05$ by LSD. Each treatment is assumed to be dependent on the other. ANOVA results of the main effects of irrigation (I), betaine (B), chitin (C), and their interaction effect $(\mathrm{B} \times \mathrm{C})$ on the agronomic performance of maize are shown as ns, ***, and *** as non-significant and significant at $p \leq 0.05,0.01$, or 0.001 , respectively

Table 6. Effects of different concentrations of betaine and chitin on the photosynthesis and water use efficiency (WUE $\left.E_{i}, W^{\prime} E_{y i e l d}, W E_{b i o m a s s}\right)$ of maize under full irrigation (FI) and regulated deficit irrigation (RDI).

\begin{tabular}{|c|c|c|c|c|c|c|c|c|}
\hline $\begin{array}{l}\text { Irrigation } \\
\text { Treatments }\end{array}$ & $\begin{array}{c}\text { Betaine } \\
(\mathrm{mM})\end{array}$ & $\begin{array}{l}\text { Chitin } \\
\text { (g/kg) }\end{array}$ & SPAD Value & $\begin{array}{l}\text { Transpiration } \\
\left(\mu \mathrm{mol} \mathrm{m}^{-2} \cdot \mathrm{s}^{-1}\right)\end{array}$ & $\begin{array}{l}\text { Net Photosynthesis } \\
\left(\mathrm{mmol} \mathrm{m}^{-2} \cdot \mathrm{s}^{-1}\right)\end{array}$ & $\begin{array}{c}\mathrm{WUE}_{\mathrm{i}} \\
\left(\mathrm{mmol} \mathrm{CO}{ }_{2} \cdot \mathrm{mol}^{-1} \mathrm{H}_{2} \mathrm{O}\right)\end{array}$ & $\begin{array}{l}\text { WUE }{ }_{\text {yield }} \\
\left(\mathrm{kg} \mathrm{m}^{-3}\right)\end{array}$ & $\begin{array}{l}\text { WUE }_{\text {biomass }} \\
\left(\mathbf{k g} \cdot \mathbf{m}^{-3}\right)\end{array}$ \\
\hline FI & 0 & 0 & $17.29 \mathrm{~d}$ & $1.04 \mathrm{a}$ & $10.69 \mathrm{~b}$ & $10.10 \mathrm{~b}$ & $0.61 \mathrm{c}$ & $0.18 \mathrm{~b}$ \\
\hline RDI & 0 & 0 & $10.72 \mathrm{e}$ & $0.55 \mathrm{~b}$ & $3.80 \mathrm{c}$ & $7.97 \mathrm{c}$ & $0.55 \mathrm{c}$ & $0.17 \mathrm{~b}$ \\
\hline RDI & 50 & 0 & $22.18 \mathrm{c}$ & $0.97 \mathrm{a}$ & $13.16 \mathrm{~b}$ & $14.30 \mathrm{a}$ & $4.05 \mathrm{~b}$ & $1.47 \mathrm{a}$ \\
\hline RDI & 0 & 2 & $31.47 \mathrm{a}$ & $0.96 \mathrm{a}$ & $16.20 \mathrm{a}$ & $16.86 \mathrm{a}$ & $13.54 \mathrm{a}$ & $2.96 \mathrm{a}$ \\
\hline RDI & 50 & 2 & $26.23 \mathrm{~b}$ & $1.05 \mathrm{a}$ & $12.13 \mathrm{~b}$ & $11.64 \mathrm{~b}$ & $9.46 \mathrm{a}$ & $2.00 \mathrm{a}$ \\
\hline \multicolumn{9}{|c|}{ Source of variation } \\
\hline \multicolumn{3}{|c|}{ Irrigation treatments (I) } & * & ** & $* * *$ & * & * & * \\
\hline \multicolumn{3}{|c|}{ betaine concentration (B) } & ns & ns & * & * & ns & ns \\
\hline \multirow{2}{*}{\multicolumn{3}{|c|}{$\begin{array}{c}\text { chitin concentration }(\mathrm{C}) \\
\mathrm{B} \times \mathrm{C}\end{array}$}} & $* * *$ & ns & $* *$ & * & ns & ns \\
\hline \multicolumn{2}{|c|}{$B \times C$} & & $* * *$ & ns & $* * *$ & $* * *$ & * & * \\
\hline
\end{tabular}

Data were recorded and calculated after 8 weeks of irrigation and chemical treatments from six replicates. Means in the same column within treatments followed by different letters are significantly different at $p \leq 0.05$ by LSD. Each treatment is assumed to be dependent on the other. ANOVA results of the main effects of irrigation (I), betaine (B), chitin (C), and their interaction effect $(\mathrm{B} \times \mathrm{C})$ on the photosynthesis and water use efficiency of maize are shown as ns, ${ }^{*}, * *$, and ${ }^{* *}$ as non-significant and significant at $p \leq 0.05,0.01$, or 0.001 , respectively. 


\section{Conclusions}

We studied the effects of optimal concentrations of betaine and chitin treatments on the changes in yield and WUE in maize under RDI conditions. Biostimulant treatment with betaine and chitin increased the tolerance of maize to water stress by exhibiting markedly higher yield-related traits, photosynthesis parameters, and WUE values under RDI than untreated plants. Compared to the mixture treatment and controls, treatments with $2 \mathrm{~g} / \mathrm{kg}$ chitin or $50 \mathrm{mM}$ betaine alone ameliorate water stress and can be used as a substitute technology for developing WUE plants and improving plant yields, resulting in increased farm income. Furthermore, the SPAD developed in this study for evaluating and screening the photosynthesis and WUE parameters of maize plants under RDI is a nondestructive and applicable way to assess seedlings grown on a large scale in open fields. These findings may have greater significance for farming in dry lands and offer information for further physiological studies on maize WUE and water stress tolerance. Further studies are needed to confirm the specific signal regulation and transduction components that are present in chitin or betaine-mediated improvements of water stress tolerance in 'White Pearl' maize through genetic modification or mutagenesis.

Supplementary Materials: The following are available online at http://www.mdpi.com/2073-4395/9/9/559/s1, Figure S1: The total amount of water applied to Zea. mays 'White Pearl' from the first day up to the 56th day under FI and RDI with different concentrations of betaine, chitin, and betaine and chitin.

Author Contributions: Conceived and designed the experiments: Y.-S.C. and C.-W.W. Performed the experiments and analyzed the data: F.-W.L. Wrote the paper: K.-H.L. All authors approved the final manuscript.

Funding: This work was financially supported by the National Taiwan University from Excellence Research Program-Core Consortiums (NTUCCP-107L891301, NTU-108L8806), and the NTU Research Center for Future Earth from The Featured Areas Research Center Program within the framework of the Higher Education Sprout Project by the Ministry of Education (MOE) in Taiwan, and the Ministry of Science and Technology of the Republic of China (MOST108-2811-M-002 -609).

Conflicts of Interest: The authors declare no competing financial interests.

\section{References}

1. Garces-Restrepo, C.; Giovanni, M. Irrigation Management Transfer: Worldwide Efforts and Results; Water Reports; FAO: Rome, Italy, 2008; p. 32.

2. Payero, J.O.; Tarkalson, D.D.; Irmak, S.; Davison, D.; Petersen, J.L. Effect of timing of a deficit-irrigation allocation on corn evapotranspiration, yield, water use efficiency and dry mass. Agric. Water Manag. 2009, 96, 1387-1397. [CrossRef]

3. Wang, H.X.; Liu, C.M.; Zhang, L. Water-saving agriculture in China: An overview. Adv. Agron. 2002, 75, $135-171$.

4. Mansouri-Far, C.; Sanavy, S.A.M.M.; Saberali, S.F. Maize yield response to deficit irrigation during low-sensitive growth stages and nitrogen rate under semi-arid climatic conditions. Agric. Water Manag. 2010, 97, 12-22. [CrossRef]

5. Yi, L.; Yang, S.J.; Li, S.Q.; Chen, X.; Chen, F. Growth and development of maize (Zea mays L.) in response to different field water management practices: Resource capture and use efficiency. Agric. For. Meteorol. 2010, 150, 606-613. [CrossRef]

6. Djaman, K.; Irmak, S.; Rathje, W.R.; Martin, D.L.; Eisenhauer, D.E. Maize evapotranspiration, yield production functions, biomass, grain yield, harvest index, and yield response factors under full and limited irrigation. Am. Soc. Agri. Biol. Eng. 2013, 56, 273-293.

7. Souza, T.C. Morphophysiology, morphoanatomy, and grain yield under field conditions for two maize hybrids with contrasting response to drought stress. Acta Physiol. Plant. 2013, 35, 3201-3321. [CrossRef]

8. Paredes, P.; de Melo-Abreu, J.P.; Alves, I.; Pereira, L.S. Assessing the performance of the FAO Aqua Crop model to estimate maize yields and water use under full and deficit irrigation with focus on model parameterization. Agric. Water Manag. 2014, 144, 81-97. [CrossRef] 
9. Kresovic, B.; Tapanarova, A.; Tomić, Z.; Životić, L.; Vujović, D.; Sredojević, Z. Grain yield and water use efficiency of maize as influenced by different irrigation regimes through sprinkler irrigation under temperate climate. Agric. Water Manag. 2016, 169, 34-43. [CrossRef]

10. Comas, L.H.; Thomas, J.T.; Kendall, C.D.; Zhang, H.; Gleason, S.M. Water productivity under strategic growth stage-based deficit irrigation in maize. Agric. Water Manag. 2019, 212, 433-440. [CrossRef]

11. Costa, J.M.; Vaz, M.; Escalona, J.; Egipto, R.; Lopes, C. Modern viticulture in southern Europe: Vulnerabilities and strategies for adaptation to water scarcity. Agric. Water Manag. 2016, 164, 5-18. [CrossRef]

12. Marsal, J.; Casadesus, J.; Lopez, G.; Mata, M.; Bellvert, J.; Girona, J. Sustainability of regulated deficit irrigation in a mid-maturing peach cultivar. Irrig. Sci. 2016, 34, 201-208. [CrossRef]

13. Galindo, A.; Collado-Gonzalez, J.; Grinan, I.; Corell, M.; Centeno, A.; Martin-Palomo, M.J. Deficit irrigation and emerging fruit crops as a strategy to save water in Mediterranean semiarid agrosystems. Agric. Water Manag. 2018, 202, 311-324. [CrossRef]

14. Fereres, E.; Goldhamer, D.A.; Sadras, V.O. Yield response to water of fruit trees and vines: Guidelines. In Crop Yield Response to Water Irrigation and Drainage Paper, 2nd ed.; Steduto, P., Hsiao, T.C., Fereres, E., Raes, D., Eds.; FAO: Rome, Italy, 2012; pp. 246-295.

15. Roccuzzo, G.; Villalobos, F.J.; Testi, L.; Fereres, E. Effects of water deficits on whole tree water use efficiency of orange. Agric. Water Manag. 2014, 140, 61-68. [CrossRef]

16. Ji, X.W.; Cheng, Z.Y.; Zhao, X. Effect of regulated deficit drip irrigation on yield and quality of wine grape in desert oasis. J. Arid. Land. Res. Environ. 2015, 4, 184-188.

17. Rop, D.K.; Kipkorir, E.C.; Taragon, J.K. Effects of deficit irrigation on yield and quality of onion crop. J. Agric. Sci. 2016, 8, 112-126. [CrossRef]

18. Calvo, P.; Nelson, L.; Kloepper, J.W. Agricultural uses of plant biostimulants. Plant Soil 2014, 383, 31-41. [CrossRef]

19. Patrick, D.J. Plant biostimulants: Definition, concept, main categories and regulation. Sci. Hortic. 2015, 196, 3-14.

20. Pruszyński, S. Place biostimulators in crop protection and fertilization. Wieś Jutra 2008, 5, $23-25$.

21. Ahmad, R.; Lim, C.J.; Kwon, S. Glycine betaine: A versatile compound with great potential for gene pyramiding to improve crop plant performance against environmental stresses. Plant Biotechnol. Rep. 2013, 7, 49-57. [CrossRef]

22. Hidangmayum, A.; Padmanabh, D.; Deepmala, K.; Akhouri, H. Application of chitosan on plant responses with special reference to abiotic stress. Physiol. Mol. Biol. Plant. 2019, 25, 313-326. [CrossRef]

23. Rady, M.O.A.; Semida, W.M.; El-Mageed, T.A.; Hemida, K.A.; Rady, M.M. Up-regulation of antioxidative defense systems by glycine betaine foliar application in onion plants confer tolerance to salinity stress. Sci. Hortic. 2018, 240, 614-622. [CrossRef]

24. Katiyar, D.; Hemantaranjan, A.; Singh, B. Chitosan as a promising natural compound to enhance potential physiological responses in plant: A review. Indian J. Plant Physiol. 2015, 20,1-9. [CrossRef]

25. Sharif, R.; Mujtaba, M.; Rahman, M.; Shalmani, A.; Ahmad, H.; Anwar, T.; Tianchan, D.; Wang, X. The multifunctional role of chitosan in horticultural crops: A review. Molecules 2018, 23, 872. [CrossRef]

26. Giri, J. Glycinebetaine and abiotic stress tolerance in plants. Plant Signal. Behav. 2011, 6, 1746-1751. [CrossRef]

27. You, L.; Song, Q.; Wu, Y.; Li, S.; Jiang, C.; Chang, L.; Yang, X.; Zhang, J. Accumulation of glycine betaine in transplastomic potato plants expressing choline oxidase confers improved drought tolerance. Planta 2019, 249, 1963-1975.

28. Wakrim, R.; Wahbi, S.; Tahi, H.; Aganchich, B.; Serraj, R. Comparative effects of partial root drying (PRD) and regulated deficit irrigation (RDI) on water relations and water use efficiency in common bean (Phaseolus vulgaris L.). Agric. Ecosyst. Environ. 2005, 106, 275-287. [CrossRef]

29. Fischer, R.A.; Turner, N.C. Plant productivity in the arid and semiarid zones. Annu. Rev. Plant Physiol. 1978, 29, 277-317. [CrossRef]

30. Amor, F.M.D.; Cuadra-Crespo, P.; Walker, D.J.; Camara, J.M.; Madrid, R. Effect of foliar application of antitranspirant on photosynthesis and water relations of pepper plants under different levels of CO2, and water stress. J. Plant Physiol. 2010, 167, 1232-1238. [CrossRef]

31. Wutipraditkul, N.; Wongwean, P.; Buaboocha, T. Alleviation of salt-induced oxidative stress in rice seedlings by proline and/or glycine betaine. Biol. Plant. 2015, 59, 547-553. [CrossRef]

32. Wang, N.; Cao, F.; Marvin, E.; Ambrose, R.; Qiu, C.; Wu, F. Foliar application of betaine improves water deficit stress tolerance in barley (Hordeum vulgare L.). Plant Growth Regul. 2019, 89, 109-118. [CrossRef] 
33. Ali, S.; Chaudhary, A.; Rizwan, M.; Anwar, H.T.; Adrees, M.; Farid, M.; Irshad, M.K.; Hayat, T.; Anjum, S.A. Alleviation of chromium toxicity by glycine betaine is related to elevated antioxidant enzymes and suppressed chromium uptake and oxidative stress in wheat (Triticum aestivum L.). Environ. Sci. Pollut. Res. 2015, 22, 10669-10678. [CrossRef]

34. Shams, M.; Yildirim, E.; Ekinci, M.; Turan, M.; Dursun, A.; Parlakova, F.; Kul, R. Exogenously applied glycine betaine regulates some chemical characteristics and antioxidative defence systems in lettuce under salt stress. Hortic. Environ. Biotechnol. 2016, 57, 225-231. [CrossRef]

35. Jabeen, N.; Abbas, Z.; Iqbal, M.; Rizwan, M.; Jabbar, A.; Farid, M.; Ali, S.; Ibrahim, M.; Abbas, F. Glycine betaine mediates chromium tolerance in mung bean through lowering of $\mathrm{Cr}$ uptake and improved antioxidant system. Arch. Agron. Soil Sci. 2016, 62, 648-662. [CrossRef]

36. Yao, W.; Xu, T.; Farooq, S.U.; Jin, P.; Zheng, Y. Glycine betaine treatment alleviates chilling injury in zucchini fruit (Cucurbita pepo L.) by modulating antioxidant enzymes and membrane fatty acid metabolism. Postharv. Biol. Technol. 2018, 144, 20-28. [CrossRef]

37. Wani, S.H.; Singh, N.B.; Haribhushan, A.; Mir, J.I. Compatible solute engineering in plants for abiotic stress tolerance - role of glycine betaine. Curr. Genom. 2013, 14, 157-165. [CrossRef]

38. Korkmaz, A.; Deger, O.; Kocacinar, F. Alleviation of water stress effects on pepper seedlings by foliar application of glycine betaine. N. Z. J. Crop Hortic. Sci. 2015, 43, 18-31. [CrossRef]

39. Chaum, S.; Samphumphuang, T.; Kirdmanee, C. Glycine betaine alleviates water deficit stress in indica rice using proline accumulation, photosynthetic efficiencies, growth performances and yield attributes. Aust. J. Crop Sci. 2013, 7, 213-218.

40. Hamid, R.M.; Mohammad, A. The interaction effect of drought and exogenous application of glycine betaine on corn (Zea mays L.). Eur. J. Exp. Biol. 2013, 3, 197-206.

41. Yu, J.; Shainberg, I.; Yan, Y.L.; Shi, J.G.; Levy, G.J.; Mamedov, A.I. Super absorbents and semiarid soil properties affecting water absorption. Soil Sci. Soc. Am. J. 2011, 75, 2305-2313. [CrossRef]

42. Martins, M.; Carvalho, M.; Carvalho, D.T.; Barbosa, S.; Doriguetto, A.C.; Magalhaes, P.C.; Ribeiro, C. Physicochemical characterization of chitosan and its effects on early growth, cell cycle and root anatomy of transgenic and non-transgenic maize hybrids. Aust. J. Crop. Sci. 2018, 12, 56. [CrossRef]

43. Li, Z.; Zhang, Y.; Zhang, X.; Merewitz, E.; Peng, Y.; Ma, X.; Yan, Y. Metabolic pathways regulated by chitosan contributing to drought resistance in white clover. J. Proteom. Res. 2017, 16, 3039-3052. [CrossRef]

44. Pirbalouti, A.G.; Malekpoor, F.; Salimi, A.; Golparvar, A. Exogenous application of chitosan on biochemical and physiological characteristics, phenolic content and antioxidant activity of two species of basil (Ocimum ciliatum and Ocimum basilicum) under reduced irrigation. Sci. Hortic. 2017, 217, 114-122. [CrossRef]

45. Khan, W.M.; Prithiviraj, B.; Smiyh, D.L. Effect of foliar application of chitinoligosaccharides on photosynthesis of maize and soybean. Photosynth 2002, 40, 621-624. [CrossRef]

46. Dos Reis, C.O.; Magalhaes, P.C.; Roniel, G.A.; Lorena, G.A.; Valquiria, M.R.; Diogo, T.C. Action of N-Succinyl and N,O-Dicarboxymethyl Chitosan Derivatives on Chlorophyll Photosynthesis and Fluorescence in Drought-Sensitive Maize. J. Plant Growth Regul. 2019, 38, 619-630. [CrossRef]

47. Rabêlo, V.M.; Magalhães, P.C.; Bressanin, L.A.; Carvalho, D.T. The foliar application of a mixture of semisynthetic chitosan derivatives induces tolerance to water deficit in maize, improving the antioxidant system and increasing photosynthesis and grain yield. Sci. Rep. 2019, 9, 8164. [CrossRef]

48. Kurita, K. Chitin and chitosan: Functional biopolymers from marine crustaceans. Mar. Biotechnol. 2006, 8 , 203-226. [CrossRef]

49. Rahbarian, R.; Khavari-Nejad, R.; Ali, G.; Abdolreza, B.; Farzaneh, N. Drought stress effects on photosynthesis, chlorophyll fluorescence and water relations in tolerant and susceptible chickpea (Cicer Arietinum L.) genotypes. Acta Biol. Crac. Ser. Bot. 2011, 53, 47-56. [CrossRef]

50. Bonneville, M.; Fyles, J.W. Assessing variations in SPAD-502 Chlorophyll meter measurements and their relationships with nutrient content of trembling aspen foliage. Commun. Soil Sci. Plant Anal. 2006, 37, 525-539. [CrossRef]

(C) 2019 by the authors. Licensee MDPI, Basel, Switzerland. This article is an open access article distributed under the terms and conditions of the Creative Commons Attribution (CC BY) license (http://creativecommons.org/licenses/by/4.0/). 